\title{
1. Introduction to EU Public Procurement and Innovation
}

Innovation is nowadays categorized as an umbrella policy of the EU. ${ }^{1}$ This is driving the EU to reshape several areas in which it has legal competence. These reforms aim to transform these areas into more innovation-friendly systems, to tap the potential for innovation to promote economic growth and help address the social and environmental challenges of the new era. ${ }^{2}$ Therefore, bearing in mind the importance of public procurement in the European arena, it is logical that the legislative framework should be revised in order to transform this legal subject into a driver of innovation.

The new EU legislative package for procurement - in particular, Directive $2014 / 24 / \mathrm{EU}^{3}$ - has effected several reforms in order to tackle possible hindrances to the promotion of innovation within the legislative framework. Moreover, the European Commission seems to view the promotion of innovation through public procurement as the perfect tool to address cost efficiencies and environmental and social concerns in a balanced and competitive way. ${ }^{4}$ This is also symptomatic of a wider phenomenon in which the EU increasingly views public procurement as a strategic system to promote EU policies. One of the most important measures has been the creation of a tailor-made procurement procedure: the innovation partnership procedure (Article 31 of Directive 2014/24/EU). ${ }^{5}$ This procedure is intended, inter alia, to provide

1 See C Edquist, 'Striving Towards a Holistic Innovation Policy in European Countries - But Linearity Still Prevails!' (2014) 5(2) Science Technology and Innovation Policy Review 1-19; J Elder and J Fangerber, 'Innovation Policy: What, Why, and How' (2017) 33(1) Oxford Review of Economic Policy 2-23.

${ }^{2} \mathrm{~K}$ Gretschmann and S Schepers, 'Revisiting Innovation: Revolutionising European Innovation Policy by Means of an Innovation Ecosystem' in K Gretschmann and S Schepers (eds), Revolutionising EU Innovation Policy (Palgrave Macmillan, 2016) pp 1-27; V Reillon, EU Innovation Policy - Part I: EU Policies and Instruments Supporting Innovation (European Parliamentary Research Service, 2016) pp 3-5.

3 Directive 2014/24/EU of the European Parliament and the Council on public procurement and repealing Directive 2004/18/EC [2014] OJ L94/65.

4 European Commission, 'Guidance on Innovation Procurement', Brussels, $\operatorname{COM}(2018) 3051$ final, 15 May 2018, pp 3-6.

5 On this new procedure, see P Cerqueira Gomes, 'The Innovative Innovation Partnerships under the 2014 Public Procurement Directives' (2014) 4 Public 
more flexibility in order to promote increased cooperation between public and private entities, so as to facilitate the creation of innovative goods, services or works to satisfy a specific public need.

Having described the background, this book will investigate whether the $\mathrm{EU}$, merely by harmonizing laws through the creation of a complex procedure such as the innovation partnership procedure, can increase innovation procurement in the public sector for all Member States. With this in mind, this book will explore in detail the main stages and features of the innovation partnership procedure. Simultaneously, in describing and analysing the innovation partnership procedure, this book will also highlight those aspects of this new procedure that may be regarded as challenges of the harmonization process, due to the novelty and specific characteristics of the innovation partnership procedure.

This book will focus on the Procurement Directive for the public sector (Directive 2014/24/EU). Consequently, the utilities ${ }^{6}$ and defence sectors ${ }^{7}$ will not be covered, due to their specificities regarding the applicable legislative framework and the market in which contracting authorities operate.

Procurement Law Review 211-18; S Arrowsmith, The Law of Public and Utilities Procurement, vol I (3rd edn) (Sweet \& Maxwell, 2014) pp 1046-60; P Telles and L Butler, 'Public Procurement Award Procedures in Directive 2014/24/EU' in F Lichère, R Caranta and S Treumer (eds), Modernising Public Procurement: The New Directive (Djof Publishing, 2014) pp 131-85; M Andrecka, 'Innovation Partnership in the New Public Procurement Regime - A Shift of Focus from Procedural to Contractual Issues?' (2015) 2 Public Procurement Law Review 48-62.

6 Directive 2014/25/EU of the European Parliament and the Council on procurement by entities operating in the water, transport, energy and postal services sectors and repealing Directive 2004/17/EC [2014] OJ L94/243.

7 Directive 2009/81/EC on the coordination of procedures for the award of certain works contracts, supply contracts and services contracts by contracting authorities or entities in the field of defence and security, and amending Directive 2004/17/EC and 2004/18/EC [2009] OJ L216/76. 